\title{
INVESTIGATION OF LIPOPHYILIC COMPOUNDS FROM NATIVE SPECIES OF PORTULACA L. (PORTULACEAE) GENUS
}

\author{
ADRIANA IULIANA ANGHEL ${ }^{1 *}$, VALERIA RĂDULESCU ${ }^{2}$, DIANA-CAROLINA ILIEŞ ${ }^{2}$, \\ MIHAELA DINU $^{1}$, VIORICA ISTUDOR ${ }^{3}$, IOANA NENCU ${ }^{3}$, ROBERT VIOREL ANCUCEANU ${ }^{1}$ \\ "Carol Davila" University of Medicine and Pharmacy, Faculty of Pharmacy, 6 Traian Vuia Street, 020956, Bucharest, Romania \\ ${ }^{I}$ Pharmaceutical Botany Department \\ ${ }^{2}$ Organic Chemistry Department \\ ${ }^{3}$ Pharmacognosy, Phytochemistry and Phytotherapy Department
}

*corresponding author: anghel_adriana_iuliana@yahoo.com

Manuscript received: January 2018

\begin{abstract}
The species of Portulaca genus are little known, studied and are not used in Romania for therapy or food purposes. In the world, though, Portulaca oleracea is known for its therapeutic and nutritive value. This research aimed the investigation of some lipophilic compounds from two Romanian native species, P. oleracea and P. grandiflora. The analysis of volatile compounds was carried out by GC-MS and the total carotenoids were spectrophotometrically assayed. In P. oleracea 17 volatile compounds were identified, among which the most important were linalool (33.18\%) and salicylaldehyde (21.23\%). Their presence might justify the use of the species in the therapy of diabetes and its complications, as well as in inflammatory states. The total carotenoid content was higher for P. oleracea (between $281.3-361.9 \mathrm{mg}$ carotene per 100 grams of dried herbal product) than for $P$. grandiflora (between 6.4 - 6.6). The results are in agreement with the antioxidant activity reported for the herbal product in the literature.
\end{abstract}

\section{Rezumat}

Speciile genului Portulaca sunt puţin cunoscute, studiate şi sunt neutilizate în terapie sau alimentaţie la noi în ţară. În lume însă, Portulaca oleracea este cunoscută pentru valoarea sa nutritivă şi terapeutică. Cercetarea de faţă urmăreşte investigarea unor compuşi lipofili din două specii autohtone, $P$. oleracea şi $P$. grandiflora. Analiza compuşilor volatili a fost realizată prin GC-MS, iar carotenoidele totale au fost determinate spectrofotometric. În P. oleracea au fost identificaţi 17 compuşi volatili, dintre care cei mai importanţi au fost linaloolul $(33,18 \%)$ şi salicilaldehida $(21,23 \%)$. Prin prezenţa acestor compuşi, specia poate fi utilă în terapia diabetului şi a complicaţiilor sale, precum şi în diferite stări inflamatorii. Conţinutul în carotenoide totale a fost mai mare pentru $P$. oleracea (între $281,3-361,9 \mathrm{mg}$ caroten/100 g produs vegetal uscat) faţă de $P$. grandiflora (între 6,4 - 6,6 mg caroten/100 g produs vegetal uscat). Rezultatele sunt în concordanţă cu acţiunea antioxidantă, menționată în literatura de specialitate.

Keywords: Portulaca oleracea, $P$. grandiflora, antioxidant, caroten

\section{Introduction}

The genus Portulaca (Portulacaceae family) is represented in Romania by two species, $P$. oleracea L. and P. grandiflora Hook. Portulaca oleracea L. (common purslane) has been traditionally used as food and in the treatment of digestive conditions, as an anthelmintic. In the scientific literature, various reports are available claiming its use in a number of conditions, some of them supported by scientific data; data on its chemical composition have also been published [20]. The species growing in Romania has never been investigated up to now, although it is widespread, even invasive in some cultures, producing a large number of seeds and being little-demanding. Portulaca grandiflora Hook (moss-rose purslane) is a species cultivated for its beautifully coloured flowers and its resistance to environmental conditions. Little research has been carried out on the chemical composition and pharmacognosy of Portulaca grandiflora $[5,6]$. The studies published by now have reported analgesic, antimutagenic and lymphocyte stimulating activities [3, 24, 35].

Essential oils are a complex class of secondary metabolites synthesized by plants usually in very low amounts $(<1 \%)$. The composition of secondary metabolites varies with the season, day time, environmental conditions, as well as the genetic material of the plant $[4,7,29]$.

The essential oils from Portulaca genus have been little investigated by now. We only identified two reports on the chemical composition of essential oils of some species from China [25, 36].

Carotenoids are compounds universally widespread, being fond both in lower organisms such as bacteria, 
algae, fungi, lichens or ferns, as well as in higher organisms $[9,26]$.

Previous phytochemical studies have investigated carotenoids only in the species $P$. oleraceea, while for $P$. grandiflora no reports have been identified in this sense in the literature. Varieties of $P$. oleracea growing in Europe have been checked for their $\beta$ carotene contents in experiments focused on this species only or in comparison with other species [17]. The content in carotenoidic pigments seems to depend on a series of environmental factors, such as soil composition, temperature, light (intensity, illumination time). These factors are different from those affecting the varieties which have been investigated in previous research on $P$. oleracea . Besides, $P$. grandiflora has not been investigated at all from this perspective. In a previous study we have reported on the phytochemical screening of the two species, which inter alia, by specific chemical reactions, signalled the presence of lipophilic compounds: sterols, carotenoids [5] and flavonoid aglycons. In addition, as stated above, the literature mentions the presence of essential oils in Portulaca species [25, 36]. We have therefore proceeded to qualitatively and quantitatively assess the essential oils and total carotenoids in the two species of the Portulaca genus.

\section{Materials and Methods}

Both species have been harvested fresh from Bucharest, Romania in September. A voucher specimen was deposited in the Herbarium of the Faculty of Pharmacy, "Carol Davila" University of Medicine and Pharmacy, Bucharest, Romania. The purity and quality of the plant material were determined using the relevant methods described in the European Pharmacopoeia, $7^{\text {th }}$ Edition. The above-ground parts of $P$. oleracea and $P$. granadiflora were subjected to distillation for 4 hours. The ratio herbal product water was $1 / 5(\mathrm{~g} / \mathrm{mL})$ for $P$. oleracea and $1 / 7(\mathrm{~g} / \mathrm{mL})$ for $P$. granadiflora. The hydrodistillate obtained was analysed by GC-MS.

Chemicals

Dichloromethane Suprasolv for gas-chromatography, methanol and $\mathrm{C}_{18}$ cartridge $(500 \mathrm{mg}$ ) were purchased from Merck, Darmstadt, Germany. The n-alkanes C8 C20 solutions in hexane used for the determination of Kovats indices were also purchased from Merck. Volatile compounds extraction

Fresh plant material and water 1:5 g/mL was hydrodistilled in a Neo Clevenger apparatus for $4 \mathrm{~h}$. The hydrodistillate obtained was passed through a conditioned $500 \mathrm{mg} \mathrm{C}_{18}$ cartridge according to a method published earlier [32]. The compounds were eluted with $2 \mathrm{~mL}$ dichloromethane and $1 \mu \mathrm{L}$ of eluate were injected in the system for the GC-MS analysis.
Gas-chromatography - mass spectrometry assay GC-MS analysis of dichloromethane extract of Portulaca oleracea was carried out using a Fisons Instruments GC 8000 with an electron impact quadrupole, MD 800 mass spectrometer detector. The electron ionisation energy was $70 \mathrm{eV}$. A fused silica column $5 \%$ phenylpoly(dimethylsiloxane) (SLB - $5 \mathrm{~ms}, 30 \mathrm{~m}$ x $0.32 \mathrm{~mm}$ i.d., film thickness $=0.25 \mu \mathrm{m}$ ) was employed. The operating conditions were the following: a splitsplitless injector (split ratio, $1 / 30$ ) at $280^{\circ} \mathrm{C}$, ionsource temperature $200^{\circ} \mathrm{C}$ and the interface temperature $280^{\circ} \mathrm{C}$; initial column temperature, $40^{\circ} \mathrm{C}$ for $3 \mathrm{~min}$, raised at $5 \% \mathrm{~min}$ to $250^{\circ} \mathrm{C}$ and finally held isothermally for $10 \mathrm{~min}$; the carrier gas (helium) flow rate was $2 \mathrm{~mL} / \mathrm{min}$; sample volume injected, $1 \mu \mathrm{L}$. Data acquisition was performed with MassLab Software for the mass range 30-600 $\mathrm{u}$ with a scan speed of $1 \mathrm{scan} / \mathrm{s}$. The identity of dichloromethane extract components was established from their GC Kovats retention indices and from mass spectra by computer matching with mass spectra library (NIST, WILEY and a personal library of 600 spectra). The linear retention indices were determined in relation to a homologous series of n-alkanes (C8 - C20). The experimental value of Kovats indices were compared with those reported in literature [2]. Component relative concentrations were calculated from GC peak areas without using correction factors.

\section{Carotenoids assay}

For the total carotenoid assay, the dried, comminuted herbal product from the two species was used. It was assessed the intensity of colour of an etheric solution obtained after carotenoid saponification with $\mathrm{KOH} 10 \%$ versus a reference substance $(\beta$ carotene).

Preparation of extractive solutions

The extraction was carried out with a Soxhlet apparatus using ethyl ether as a solvent. $2 \mathrm{~g}$ of herbal product were extracted until the solution became colourless. The ether solution was concentrated to $10-12 \mathrm{~mL}$.

Saponification was performed with $10 \mathrm{~mL} \mathrm{KOH} 10 \%$ (in methanol) for 1 - 2 hours. By saponification, chlorophyll was removed and carotenoid esters were hydrolysed. After cooling, to the obtained sample, 2 - 3 volumes of water were added and it was subjected to 5 - 6 successive extractions with ethyl ether. The pooled etheric solutions were passed through anhydrous sodium sulphate and brought in a volumetric flask of $100 \mathrm{~mL}[12,27]$.

The assay of total carotenoids of the obtained samples was carried out using a calibration curve prepared from a reference solution (stock) of $\beta$-carotene (Merk) $2.5 \mathrm{mg} / 100 \mathrm{~mL}$ in benzene. The calibration curve included concentrations ranging between 2.5 and $17.5 \mu \mathrm{g} / 100 \mathrm{~mL}$ was prepared. The determination coefficient $\left(\mathrm{r}^{2}\right)$ was 0.9998 and the regression equation, $\mathrm{y}=0.0185 \mathrm{x}-0.0013$. 


\section{Results and Discussion}

The hydrodistillation of $P$. grandiflora herbal product did not manage to separate any essential oil and the analysis of the sample obtained by washing the

apparatus with $2 \mathrm{~mL} \mathrm{CH}_{2} \mathrm{Cl}_{2}$ did not allow obtaining a chromatographic fingerprint for this species.

Table I shows the relative content of Portulaca oleracea dichloromethane extract components, expressed as percentage from total area.

Table I

The chemical composition of Portulaca oleracea dichloromethane extract

\begin{tabular}{|c|c|c|c|c|c|}
\hline No. & Compound & RT (min) & $\mathbf{K I}_{\text {exp }}$ & $\mathbf{K I}_{\text {lit }}$ & Area (\%) \\
\hline 1 & 4-hexen-1-ol & 4.45 & 873 & 879 & 4.27 \\
\hline 2 & heptanal & 5.71 & 904 & 908 & 8.25 \\
\hline 3 & 2,4-hexadienal & 6.03 & 917 & 916 & 0.80 \\
\hline 4 & benzaldehyde & 7.50 & 965 & 965 & 1.34 \\
\hline 5 & 1-heptanol & 8.01 & 980 & 978 & 0.30 \\
\hline 6 & 1-octen-3-ol & 8.25 & 986 & 986 & 0.37 \\
\hline 7 & 6-methyl-5-hepten-2-one & 8.39 & 990 & 994 & 0.38 \\
\hline 8 & 3-octanol & 8.80 & 1001 & 1001 & 0.64 \\
\hline 9 & 2,4-heptadienal & 9.22 & 1015 & 1016 & 2.14 \\
\hline 10 & salicylaldehyde & 10.15 & 1046 & 1049 & 21.23 \\
\hline 11 & linalool & 12.10 & 1102 & 1101 & 33.18 \\
\hline 12 & $\alpha$-terpineol & 14.99 & 1195 & 1195 & 2.18 \\
\hline 13 & safranal & 15.09 & 1198 & 1198 & 0.60 \\
\hline 14 & geraniol & 16.75 & 1256 & 1255 & 1.33 \\
\hline 15 & 2-methoxy-4-vinylphenol & 18.40 & 1311 & 1313 & 6.55 \\
\hline 16 & 3-damascenone & 20.28 & 1380 & 1384 & 3.47 \\
\hline 17 & cis-nerolidol & 25.04 & 1563 & 1565 & 0.41 \\
\hline \multicolumn{5}{|c|}{ TOTAL } \\
\hline
\end{tabular}

A total of 17 compounds were identified from the dichloromethane extract accounting for $87.44 \%$ of the total area. Most of the compounds identified belong to either alcohols $(42.62 \%)$ or carbonyl compounds (38.21\%) class. Among these compounds only a phenolic ether, 2-methoxy-4-vinylphenol was found in a percentage of $6.55 \%$. The most abundant compounds were linalool (33.18\%) and salicylaldehyde (21.23\%). Among the identified compounds, benzaldehyde and 2-methoxy-4-vinylphenol along with linalool derivatives were found in Portulaca oleracea L. from China [36].

Salicylaldehyde has been identified in buckwheat, being one of the constituents giving its specific flavour [21]. It also represents up to $68 \%$ of the essential oils extracted from the leaves of Filipendula vulgaris [33].

Linalool is a monoterpene frequently found in essential oils obtained from aromatic plants. It is known as an additive in the processing of food, drinks and as an ingredient in cosmetic products. It has also repellent, anxiolytic and antinociceptive activity, being potentially useful in the therapy of persistent pain and as an anti-inflammatory agent $[22,10,28]$. Some studies have shown that linalool may attenuate the risk of diabetic nephropathy occurrence, being known that is has hypoglycaemic effects. $[1,16]$.

Another monoterpene identified in the essential oil of $P$. oleracea, also found in essential oils from other plants, is $\alpha$-terpineol. Among its pharmacological activities we mention the anticonvulsant, antihypertensive, antinociceptive and antiseptic ones $[14,15$, 34, 31].

Another compound found in a larger proportion in the essential oil analysed is $\beta$-damascenone. This may be found in the essential oils of roses and in certain fruits, such as grapes, being responsible for the flavour of the red wine and it has spasmolytic activity $[13,30]$. Safranal, known as a volatile compound from Crocus sativus, has been shown to have anticonvulsant and antioxidant activities [8, 19].

The results of total carotenoid assays for the two species are shown in Table II.

Table II

Total carotenoids in the aerial parts of $P$. oleracea and $P$. grandiflora

\begin{tabular}{|c|c|c|}
\hline No. & Sample & $\mathrm{M}(\mathrm{mg} / 100 \mathrm{~g}$ on a dry basis $) \pm \mathrm{SD}$ \\
\hline 1. & P. grandiflora & $6.5 \pm 0.0001$ \\
\hline 2. & P. oleracea & $321.5 \pm 0.0404$ \\
\hline
\end{tabular}

$\mathrm{M}=$ mean, $\mathrm{DS}=$ standard deviation

$321.5 \pm 0.0404$

The total carotenoid contents, expressed in $\mathrm{mg}$ carotenoids per 100 grams of dried herbal product is 6.5 in P. grandiflora and considerably higher, 321.5 for $P$. oleracea. These results are different from those reported in the literature $(22-30 \mathrm{mg} / \mathrm{g}$ of fresh leaves) [23], probably due to the methods used for 
extraction and quantification, as well as to the differences in environmental conditions. The differences are also likely to be to a good extent attributable to the fact that in the literature assay data were reported for fresh leaves, while we have used dry herbal products consisting in the aerial parts. The results found by us are close to those reported in the literature for other species, known for their hypolipidemic activity (e.g. Zingiber officinale 0.64; Anethum graveolens $0.64 \mathrm{mg} \%$ carotenoids [11], but also similar to those reported in species known for their nutritive value and taxonomically related to Portulacaceae (Chenopodium bonus henricus $L$, $344.1 \mathrm{mg}$ total carotenoids/100 g dry weight) [18].

\section{Conclusions}

P. oleracea, by its content in linalool $(38 \%)$ and safranal $(0,6 \%)$ (although the latter is in rather modest amounts) might be useful in the treatment of diabetes and its complications; by its content in salicylaldehyde (21\%), it might have anti-inflammatory activity, while through the damascenone $(3,47 \%)$, might have spasmolytic properties. However, the relatively small amount of essential oil in the species implies the use of considerable amounts of herbal product, which might be impractical.

The carotenoids content is higher in the wild species $P$. oleracea than in the cultivated species $P$. grandiflora, and is in agreement with the reported antioxidant activity for this species.

\section{References}

1. Abou El-Soud NH, El-Lithy NA, El-Saeed GSM, Wahby MS, Khalil MY, Abou El-Kassem LT, Morsy F, Shaffie N, Efficacy of Coriandrum sativum L. essential oil as antidiabetic. J Appl Sci Res., 2012; 8(7): 3646-3655.

2. Adams RP, Identification of Essential Oils by Ion Trap Mass Spectroscopy, Academic Press, London, UK, 1996.

3. Almeida RN, Navarro DS, Barbosa-Filho JM, Plants with central analgesic activity. Phytomedicine, 2001; 8(4): 310-322.

4. Ancuceanu R, Anghel AI, Hovanet MV, Variation of iron contents, polyphenols and flavonoids in Petroselinum crispum (Mill.) Fuss (Apiaceae). Farmacia, 2018; 66(2): 275-281.

5. Anghel AI, Olaru TO, Gatea F, Dinu M, Ancuceanu RV, Istudor V, Preliminary research on Portulaca grandiflora Hook. Species (Portulacaceae) for therapeutic use. Farmacia, 2013; 61(4): 694-702.

6. Anghel AI, Ilie M, Olaru OT, Dinu M, Ancuceanu $\mathrm{RV}$, Istudor V, HPTLC qualitative and quantitative detection of sterols in species of the Portulaca genus from Romania. Farmacia, 2015; 63(5): 696-699.

7. Aprotosoaie AC, Ciocârlan N, Brebu M, Trifan A, Grădinaru AC, Miron A, Chemical composition, antioxidant and antimicrobial activities of Mentha gattefossei maire essential oil. Farmacia, 2018; 66(5): 778-782.

8. Assimopoulou AN, Sinakos Z, Papageorgiou VP, Radical scavenging activity of Crocus sativus L. extract and its bioactive constituents. Phytotherapy Research, 2005; 19 (11): 997-1000.

9. Barbosa-Filho BJM, Alencar AA, Nunes PX, de Andrade Tomaz AC, Sena-Filho JG, Athayde-Filho PF, Silva MS, Vanderlei de Souza MF, Leitão daCunha EV, Sources of alpha-, beta-, gamma-, deltaand epsilon-carotenes: A twentieth century review. Revista Brasileira de Farmacognosia, 2008; 18(1): 135-154.

10. Batista PA, Werner MF, Oliveira EC, Burgos L, Pereira P, Brum LF, Story GM, Santos AR, The antinociceptive effect of (-)-linalool in models of chronic inflammatory and neuropathic hypersensitivity in mice. J Pain, 2010; 11(11): 1222-12229.

11. Chanwitheesuk A, Teerawutgulrag A, Rakariyatham $\mathrm{N}$, Screening of antioxidant activity and antioxidant compounds of some edible plants of Thailand. Food Chem., 2005; 92: 491-497.

12. Ciulei I, Istudor V, Palade M, Niculete E, Gârd CE, Pharmacognostic analysis of vegetal products. Vol II, Ed Tehnoplast SRL, Bucharest, 1995 (available in Romanian).

13. David F, De Clerq C, Sandra P, GS-MS-MS analysis of $\beta$-damascenone in rose oil. GS-MS Varian Aplication Note, 2010, 52.

14. De Sousa DP, Quintans JL, Almeida RN, Evaluation of the anticonvulsant activity of alfa-terpineol. Pharm Biol., 2007; 45: 69-70.

15. De Sousa DP, Raphael E, Brocksom U, Brocksom $\mathrm{TJ}$, Sedative effect of monoterpene alcohols in mice: a preliminary screening. Z Naturforsch $C, 2007 ; 62$ : 563-566.

16. Deepa B, Anuradha CV, Linalool, a plant derived monoterpene alcohol, rescues kidney from diabetesinduced nephropathic changes via blood glucose reduction. Diabetologia Croatica, 2011; 40(4): 121-137.

17. Guil-Guerrero J, Garcia RI, Lipids classes fatty acids and carotenes of leaves of six edible wild plants. Eur Food Res Technol., 1999; 209(5): 313-316.

18. Hanganu D, Olah N, Vlase L, Mărculescu A, Pintea A, Chemical research of carotenoids from Chenopodium bonus henricus L. (Chenopodiaceae). Farmacia, 2012; 60(6): 840-849

19. Hosseinzadeh $\mathrm{H}$, Talebzadeh $\mathrm{F}$, Anticonvulsant evaluation of safranal and crocin from Crocus sativus in mice. Fitoterapia, 2005; 76 (7-8): 722-724.

20. Iranshahy M, Javadi B, Iranshahi M, Jahanbakhsh SP, Mahyari S, Hassani FV, Karimi G, A review of traditional uses, phytochemistry and pharmacology of Portulaca oleracea L. J. Ethnopharmacol., 2017; 205: 158-172.

21. Janeš D, Kreft $\mathrm{S}$, Salicylaldehyde is a characteristic aroma component of buckwheat groats. Food Chem., 2008; 109(2): 293-298.

22. Linck VM, da Silva AL, Figueiró M, Caramão EB, Moreno PR, Elisabetsky E, Effects of inhaled linalool in anxiety, social interaction and aggressive behavior in mice. Phytomedicine, 2010; 17(8-9): 679-683. 
23. Liu L, Howe P, Zhou YF, Xu ZQ, Hocart C, Zhan R, Fatty acids and beta-carotene in australian purslane (Portulaca oleracea) varieties. J Chromatogr A, 2000; 893(1): 207-213.

24. Liu D, Yin $X$, Wang $H$, Zhou Y, Zhang $Y$, Antimutagenicity screening of water extracts from 102 kinds of Chinese medicinal herbs. Zhongguo Zhong Yao Za Zhi, 1990; 15(10): 617-622, 640.

25. Liu LP, Jin B, Guo Z, An Q, GC-MS analysis of volatile oil of Portulaca oleracea. J Hebei Univ. (Natural Science), 1994; 14: 72-74.

26. Nencu I, Vlase L, Istudor V, Tămaş M. Preliminary research regarding Urtica urens L. and Urtica dioica L. Farmacia, 2015; 63(5): 710-715.

27. Ötleş S, Methods of Analysis of Food Components and Additives $2^{\text {ed }}$, CRC Press, 2016: 234-236.

28. Peana AT, D'Aquila PS, Panin F, Serra G, Pippia P, Moretti MD, Anti-inflammatory activity of linalool and linalyl acetate constituents of essential oils. Phytomedicine, 2002; 9(8): 721-726.

29. Pengelly A, The constituents of medicinal plants: an introduction to the chemistry \& therapeutics of herbal medicine, Crows Nest, N.S.W.: Allen \& Unwin, 2003, p.86 (available at https://epdf.tips).

30. Pineau B, Barbe JC, Leeuwen V, Dubourdieu D, which impact for $\beta$-damascenone on red wines aroma?. J Agric Food Chem., 2007; 55(10): 41034108 .
31. Quintans-Júnior LJ, Oliveira MGB, Santana MF, Santgana MT, Guimarăes AG, Siqueira JS, De Sousa DP, Almeida RN, á-terpineol reduces nociceptive behavior in mice. Pharm Biol., 2011; 49: 583-586.

32. Rădulescu V, Pavel M, Teodor A, Tănase A, Ilieş DC, Analysis of volatile compounds from infusion and hydrodistillate obtained from the species Thymus pulegioides L. (Lamiaceae). Farmacia, 2009; 57(3): 282-289.

33. Radulović N, Misić M, Aleksić J, Doković D, Palić $\mathrm{R}$, Stojanović G, Antimicrobial synergism and antagonism of salicylaldehyde in Filipendula vulgaris essential oil. Fitoterapia, 2007; 78 (7-8): 565-570.

34. Ribeiro TP, Porto DL, Menezes CP, Antunes AA, Silva DF, De Sousa DP, Nakao LS, Braga VA, Medeiros IA, Unravelling the cardiovascular effects induced by alpha-terpineol: a role for the nitric oxide-cGMP pathway. Clin Exp Pharmacol Physiol., 2010; 37: 811-816.

35. Sriwanthana B, Treesangsri W, Boriboontrakul B, Niumsakul S, Chavalittumrong P, In vitro effects of Thai medicinal plants on human lymphocyte activity. Songklanakarin J Sc. Technol., 2007; 29(1): 17-28

36. Zhu H, Wang Y, Liang H, Chen Q, Zhao P, Tao J, Identification of Portulaca oleracea L. from different sources using GC-MS and FT-IR spectroscopy. Talanta, 2001; 81(1-2): 129-135. 